\title{
Consequences of the Final Civil Decision in the Criminal Trial Pursuant to the Albanian Legislation
}

\author{
Klodjan Skënderaj \\ University of Tirana, \\ Sheshi Nënë Tereza 4, \\ Tirana 1010, Albania \\ Naim Tota \\ University of Tirana, \\ Sheshi Nënë Tereza 4, \\ Tirana 1010, Albania
}

DOI: https://doi.org/10.36941/ajis-2021-0155

\begin{abstract}
Judicial jurisdictions are separated; the criminal court has the jurisdiction to adjudicate charges brought by the prosecution, whereas other jurisdictions are exercised by the civil court and the administrative court. Thus, civil cases or in other words disputes between private entities, such as contractual obligations or inheritance issues, etc., are settled by the civil court, while disputes between individuals and public administration fall within the scope of administrative jurisdiction. Therefore, depending on the type of case, in Albania there are courts with separate judicial jurisdictions. However, in quite a few cases we might face cases where the different judicial jurisdictions are interwoven between them, in other words the consequences of a civil trial can affect the criminal trial. This paper will analyze the legal provisions in Albania, how to act in cases of resolving a case with a final civil decision in relation to facts, which are also being adjudicated in the criminal process. This paper will also analyze the role of the final civil decision in the criminal trial. Domestic court practice will be considered in terms of the impact that a civilly resolved case by a final court decision has on a criminal case.
\end{abstract}

Keywords: civil jurisdiction, criminal jurisdiction, final civil decision, adjudicated thing

\section{Introduction}

The criminal court is the authority designated by law to adjudicate charges brought by the prosecution for any of the criminal offenses provided for in the criminal code of Albania or provided in special laws. This court has the right to administer justice and according to Article 11 of the Criminal Procedure Code, no one can be found guilty and sentenced of a criminal offense without a court decision.

It is also provided that regarding the procedures that a criminal case follows; it starts with the registration of criminal proceedings by the prosecution. The latter at the end of the preliminary 
investigation can address the court of the preliminary hearing with a request to send the case for trial. After this moment in the preliminary hearing, the pre-trial judge, if he/she deems that there is sufficient evidence in support of the accusation, decides to accept the prosecutor's request and send it for trial on the merits of the case. Meanwhile, during the trial on the merits of the case, the parties, the prosecutor, and the defendant may file different procedural requests in court. The latter has the legal obligation to express itself regarding the admission or not of the various procedural requests. Upon termination of the case in the first instance, depending on the type of decision, which may be a decision to dismiss the case, a sentence, or a decision of innocence the parties have the right to appeal within 15 days from the announcement or notification of decision.

While after the case is adjudicated before the Court of Appeal, the decision of this court is considered final. This is because the parties can appeal against this decision and upon the ruling of the Supreme Court, the decision is considered final. However, in the trial on the merits of the criminal case, which is adjudicated in its entirety, i.e., by examining the evidence, we may be faced with cases when the facts settled civilly in a civil case are related to the facts being adjudicated by a criminal court. In this regard, the discussion is what the criminal court should do in these cases.

Following the basic principles outlined by the Albanian criminal procedure doctrine, the reasoning made by the Constitutional Court in its decisions has the force of law, which stems from the authority of this body to have the final say in matters on which others have already expressed a decision (Islami, H., Hoxha, A., \& Panda, I., 2012). The power of the "adjudicated case" covers not only the searches and objections made during the trial (the adjudicated element expressed), but also those that could and should have been done by filing a lawsuit, counterclaim, or objections (Lara, 2019). The literature consulted aims to support the analysis of the case law on the influence of the final decision of a civil procedure in a criminal trial, offering therefore a specific perspective to the legal institute of res judicata.

\section{Methodology}

This paper aims to offer an overview of the consequences of the final civil decision in a criminal trial based on empirical data from the Albanian judicial practice, especially after the amendments introduced in 2017 to the Albanian Code of Criminal Procedure. This approach is integrated with case law from the European Court of the Human Rights (ECtHR) as well as relevant literature review.

\section{The Case Adjudicated in the Civil Process and the Consequences in the Criminal Process}

Article 343 of the Criminal Procedure Code provides for the suspension of the main trial in cases where the termination of the criminal case depends on the settlement of a civil or administrative dispute, for which a trial is held. Thus, the court can decide to suspend the trial investigation until the civil case is settled for the same facts by a final decision. Thus, in these cases we are facing a cause, which prevents the further development of the criminal trial, without first resolving the civil case. It is understood that in these cases, we have a combination of civil and criminal trials, as essentially the same facts are being tried in both civil and criminal matters.

This combination of civil and criminal judicial jurisdictions derives from the other norm of the Criminal Procedure Code, more specifically Article 71 (Consequences of civil and administrative proceedings for the criminal one) which provides that:

"1. The final civil decision is binding on the court adjudicating the criminal case only as to whether the offense occurred, but not on the guilt of the defendant. 2. When the criminal decision depends on the resolution of a dispute over marital status or citizenship, for which a proceeding has been initiated before the competent court, the criminal court may decide, in principle, to suspend the trial investigation until the dispute is resolved by a final decision. The suspension of the trial investigation does not preclude urgent action." 
Meanwhile, if we refer to the Civil Procedure Code, the consequences of the "final civil decision" are defined in its article 451/a. More specifically, this provision stipulates that:

"The decision that has become final is binding on the parties, their heirs, persons deprived of their rights by the parties, on the court that issued the decision and all courts and other institutions. The decision that has become final shall be applied only for what has been decided between the same parties, for the same object and for the same cause. "A dispute that has been resolved by a final decision cannot be adjudicated again, unless the law provides otherwise."

Meanwhile, in order to determine the value of the constant jurisprudence of domestic courts in the interpretation of the law, for ordinary courts, the orientation of the Constitutional Court of Albania should be taken into account, where it is sanctioned that:

"The Court considers it necessary to refer to the concept of "living right", generally understood in the sense of the existence of a "constant jurisprudence", "consolidated" on a certain legal provision, thus taking into account the way it "lives" in the reality" (Constitutional Court, 2012).

Thus, in the interpretation of this decision the use of the formula of "living right" helps the court to determine the relations with ordinary judges in the field of interpretation of law, which is known as a task that belongs especially to the latter. This is because by taking a self-restraint stance in the sense that, if such a living right exists, the court takes it into account and (with some exceptions) does not stop making a different interpretation, even there where it seems most convincing to it. The authority of the court stops before the constant jurisprudential interpretation because, even in its full autonomy of trial, the court cannot ignore such an interpretation that recognizes the legislative norm its effective value in legal aspect. This is because the norms are not those that are proposed in abstract ways but those that are applied in the daily work of the judge, which aims to make them concrete and efficient.

Meanwhile, the doctrine argues that the indisputable influence of the decisions of the Constitutional Court is such that it imposes on all state bodies, not excluding even the courts, the binding power of reasoning of its decision (Islami, Hoxha, \& Panda, 2012). The reasoning made by the Constitutional Court in its decisions has the force of law, which stems from the authority of this body to have the final say in matters on which others have already spoken. Any opposite stand sets a dangerous precedent in institutional relations.

Given the powers conferred by Article 124 of the Constitution, the role and function of the Constitutional Court is to transform constitutional provisions from abstract-metaphysical to substantive and concrete through decisions, guaranteeing constitutional protection to the legal situations in which individuals are. Due to the extremely concise form of the constitutional provisions, through the decisions, i.e., the interpretation performed by the court, it becomes possible for the Constitution to be "alive", which means that the court adapts to the evolution of values in our country, guaranteeing that new values, which were probably not in the attention of the drafters of the Constitution, receive dignity, recognition and above all, constitutional protection. The very fact that the constitutional norm becomes a reality during the interpretation, i.e., during the decision-making process of the court, makes the latter without question a source of law. Moreover, it makes the court a primary source of it, taking into consideration that Article 4 of the Constitution provides that the Constitution is the highest law in the Republic of Albania.

Meanwhile, to return to the meaning of the final civil decision (as res judicata) and its legal consequences for the parties, courts and other institutions, the practice justifies that the Constitutional Court, in some of its decisions has accepted that "legal certainty is one of the essential elements of the rule of law" and this certainty implies, among other things, the "immutability of the law on regulated relations" (Barjamaj \& Dumi, p. 527). In line with the principle of legal certainty, civil procedural law has also sanctioned the principle of res judicata, a principle that prevents any new decision on what has been adjudicated. According to Article 451/a of Criminal Procedure Code, when 
the decision has become final it is binding on the parties, their heirs, persons withdrawing rights from the parties, the court that issued the decision and all courts and other institutions. "No court can adjudicate the same lawsuit against the same parties again" (Constitutional Court, 2008).

Thus, it can be said that the final court decision that constitutes an adjudicated case is an expression and concretization of the right over the legal relationship and aims to give not only clarity, but also security to this relationship. Violation of the principle of the adjudicated case would lead to the violation of the constitutional and legal rights, freedoms and interests guaranteed by Article 42 of the Constitution, i.e., to the violation of legal certainty itself. Legal certainty therefore means that, in cases where the court has finally ruled on a case, its decision should not be called into question.

In a 2006 decision, the ECtHR argues that:

"the principle according to which a final judgment is a res judicata and resolves the dispute between the parties with final effect is a fundamental element of the right to a fair trial guaranteed by Article 6 of the Convention in civil matters" (Kehaya and others v. Bulgaria, 2006, \$63).

With regard to the discussion of which part of the final civil decision constitutes an adjudicated element, it can be said that the limits of the application of the principle of the adjudicated element are determined in close connection with the substance of the dispute at trial. In this respect, the adjudicated element includes not only the orders of the enacting clause of the court decision, but also the certification of the facts and the application of the right, defined in the descriptive reasoning part of the conditional decision, to be performed for the purpose of issuing the court decision and belong to the facts or relationships that have formed the object of the trial over which the court has rendered its decision.

Regarding the obligation to implement a final civil decision as a means of exercising a judicially acquired right, I recall that the execution of a final court decision is considered as the final stage of exercising a judicially acquired right. Only after the realization of this phase can it be considered that the individual has fully put in place his/her acquired right.

In this respect in practice (Constituonal Court, 2007), it is reasoned that "in its continuing practice, the ECtHR has considered as an integral part of Article 6/1 of the ECHR the right to seek the execution of a final court decision within a reasonable time (ECtHR, Judgements of 1997 and 1997). The ECtHR has consistently stated that the applicant should not be denied the right to benefit from a favorable outcome of the proceedings (ibid).

Regarding the right to effective enforcement and within a reasonable timeframe of a final decision, the European Ministers of Justice stated in a 2001 Resolution, that:

"the full, effective and efficient enforcement of judicial decisions is essential for the purpose of to establish, strengthen and develop a judicial system that is respected by all" (Memini, p. 334).

\section{The Albanian Constitutional Court has stated that:}

"The rule of law, as one of the basic principles of a democratic society, contains the obligation of public authorities to implement final orders or court decisions. In this line of opinion, it is now accepted that the right to seek execution within a reasonable time of a final" (Constitutional Court, 2007, p. 4).

With regards to the principle of the adjudicated case, some essential aspects of the interpretation and application of the principle of the "adjudicated case" known as the principle ne bis in idem should be mentioned.

Thus, the case adjudicated in the civil process appears in two forms, the formal one and the substantial (material) one. In the formal sense, it appears as a legal state of exhaustion of the procedural means of appeal, as well as of the existence of preclusivity regarding the possibility to appeal against the final court decision. In the substantive sense, the adjudicated case is understood as a legal condition not only the impossibility of the litigants of the final court decision to reopen the 
examination of the case, but also as a right of each of them to oppose the possibility of reviewing the resolution of the case given for the dispute in a new trial.

In the interpretation and application of the law, the final court decision that has resolved the issue on the merits, constitutes a final and lasting solution of the dispute in both the constitutive and the preclusive sense. In the constitutive sense it gives the final settlement of the dispute, the positions of the opposing parties in that trial, while in the preclusive sense the possibility of seeking in court changes in the settlement of the dispute determined by the final court decision is prohibited.

The power of the "adjudicated case" covers not only the ordering part of the final decision, but also the circumstances of the case accepted at trial, the conclusions and reasons on which that decision was based, and which are related to what the court orders in the enacting clause of its decision.

If in an incoming trial issues of evidence or law are raised for discussion and examination that are essentially related to the cases for which a final court decision has been given, i.e. with a case that has been assessed, accepted and ordered by the court in that decision, even when there are litigants, object and legal cause different from that of the court decision that has become final, or even if they can be submitted as requests for the first time, then it is forbidden to enter into negotiations and trial investigation of these issues.

Thus, the authority and power of the "adjudicated case" covers not only the searches and objections made during the trial (the adjudicated element expressed), but also those that could and should have been done by filing a lawsuit, counterclaim or objections, which although not dealt with in the final decision are presumed to be inevitably part of the legal arguments, conclusions and orders of the final court decision (known as the case adjudicated silently, implied) (Lara, 2019).

\section{Application of Article 71 Paragraph 1 of the Criminal Procedure Code According to Case Law}

As mentioned above, the final civil decision is an adjudicated case and is binding on the parties and the court that issued it, but also on other courts. In the case of the criminal court, the binding nature of the final civil decision relates only to the fact whether the criminal offense occurred or not.

Seen in this aspect, although according to the wording of Article 71 of the Criminal Procedure Code, it is provided that the abidingness of the decision of the civil court is not related to the guilt of the defendant, but on the other hand it does not make sense that if there is a criminal fact than there could be no court decision to find the defendant guilty.

Thus, I share the opinion that in cases when a final civil decision which has resolved a certain case, then necessarily the criminal trial too of the case for the same facts is related to the manner of resolving the case by the civil court.

It constitutes an adjudicated case not only the enacting clause of the final decision but also the certifications of the facts and the application of the right, defined in the descriptive reasoning part of the conditional decision, that have been performed to give the court decision.

In other words, the final civil decision is binding for implementation by the criminal court regarding the existence or not of the same facts that were previously resolved by the final decision of the civil court. Procedurally, the criminal court will have to terminate the criminal trial, presenting at the same time the legal reason for the dismissal decision.

In this respect, the criminal court must implement effectively and in a reasonable time the final civil decision as it cannot adjudicate again the existence or not of these facts.

In a 2018 decision, the District Court of Tirana highlights the value of final civil decisions in criminal proceedings (District Court of Tirana, 2018). Thus, Article 71 of the Criminal Procedure Code, under the title "Consequences of civil and administrative proceedings for the criminal proceedings" expressly provides that: 
"1. The final civil decision is binding on the court that adjudicates the criminal case only in terms of the fact if the offense occurred or not, but not through the fault of the defendant. 2. When the decision depends on the resolution of a dispute over marital status or citizenship, for which a proceeding has been initiated before the competent court, the criminal court may decide, in principle, to suspend the trial investigation until the dispute is resolved by a final decision. Suspension does not prevent the performance of urgent actions".

Pursuant to Art 71 of the Criminal Procedure Code, it results that for the civil decision to have value for the criminal process, it must meet two conditions, which are: i) the civil decision of the court must have become final; and ii) must prove whether an offense objectively occurred as a fact or not. The District Court of Tirana (2018) considers in the same decision that the allegations made during the civil proceedings regarding the existence or not of a fact, which ended with a final decision, cannot be raised again in the criminal proceedings. In this case, the claims of the citizen A.Xh., regarding the fact of forged translation have been examined in the civil process and the court has not found that any forged document.

Otherwise, the provisions of the Civil Procedure Code regarding the falsity of documents would have been respected. Thus, in article 267 of the Civil Procedure Code under the title "Obligation to ensure that the private document is authentic" states that:

"When the authenticity of the private document is questioned, the applicant must be prove that, except for when the document is so amended that the court finds it difficult to ascertain that is the original one. The person to whom the private document has been submitted is obliged to immediately declare whether he/she accepts the authenticity of the signature; otherwise, the private document is considered accepted. If the authenticity of the signature is recognized or certified, the document is considered as original with the reserve of being exposed to forgery claims"

While Article 269 of this Code under the title "The procedure of comparison of documents" explicitly provides that:

"When the comparison of documents is performed, the one who presents the evidence is obliged not later than 10 days before the date set for comparison, to inform the litigant the list of documents with which the comparison will be made or to deposit the authentic documents in the court secretariat. The veracity of these documents should not be disputed. When comparable documents are in the possession of the opposing party or a third party, their submission may be required".

In case of objection, the rules provided by Article 265 of this Code shall apply. The litigant or the third person who is denied the authenticity of the writing or signature may be obliged to write before the court or the judge delegated by the letter of request a certain text with which the comparison will be made. The text is joined to the file. The court freely appreciates the refusal of the litigant or third party to write or attempt to change his/her writing. In addition, Article 270 of the Civil Procedure Code under the title "Strike for forgery" explicitly provides that:

\footnotetext{
"Any document can be struck for forgery. Private documents can be hit for forgery even when the comparison with others proves that they are authentic." As stated in the 2019 decision of the District Court of Tirana, "the authenticity of the writings, signatures and the content of a document is subject to contradictory debate. Under these circumstances, the allegations of the citizen A. Xh., regarding the forgery of the above documents constitute an adjudicated case as this allegation has been reviewed by the civil court and is already adjudicated" (Court of Appeal of Tirana, 2019).
}

Regarding to the fact again whether we are before the adjudicated case and the facts that were raised during the civil process, which has already been terminated with a final decision whether they can be raised again in the criminal process, we should refer to the practice of the Constitutional Court and that of the Supreme Court of Albania.

In one of its judgments, the Albanian Constitutional Court (2008) stated that: "The Court 
considers that the final court decision that constitutes an adjudicated case is an expression and concretization of the right over the legal relationship and aims to give not only clarity, but also security to this relationship. Violation of the principle of the adjudicated case would lead to the violation of the constitutional and legal rights, freedoms and interests guaranteed by Article 42 of the Constitution, i.e., to the violation of legal certainty itself. In the context of the case under review, legal certainty means that in cases where the court has finally ruled on a case, its decision will not be called into question".

In this respect, according to the Constitutional Court, it is accepted the stand that the adjudicated case includes not only the orders of the enacting clause of the court decision, but also the confirmation of the facts and the application of the law, defined in the descriptive reasoning part of the conditional decision being performed with the purpose of giving the court decision and to belong to the facts or relations that have formed the object of the trial on which the court has given its decision.

Regarding also to the principle of adjudicated case, for final civil decisions, as stated above in this paper in article 451 (1) of the Criminal Procedure Code provides that the decision that has become final is binding on the parties, on their heirs, persons deprived of rights by the parties, for the court that issued the decision and for all other courts and institutions.

Regarding to the principle of the adjudicated case and the Supreme Court of Albania, among others, it has been stated that: "In civil proceedings, the adjudicated case covers not only the searches, but also the objections raised, or which could and should have been filed to challenge the constitutive facts of the right claimed at trial by the plaintiff or the counterclaimant" (Supreme Court, Civil Section, 2010).

Thus, the authority and power of the adjudicated case covers not only the searches and objections made during the trial (the adjudicated case expressed), but also those that could and should have been done by filing a lawsuit, counterclaim, or objections, which although untreated in the final decision, are presumed to be inevitably part of the legal logic of the reasoning, conclusions, and orders of the final court decision (known as the adjudicated, silent, and implied case).

\section{Conclusions}

As pointed out in this paper, in many cases we may face dilemmas as to what will be understood with the consequences of civil proceedings in criminal proceedings, thus cases where a final civil decision has adjudicated certain facts. Thus, how will the criminal court act if it is faced with the same facts on which the accusation has been raised. The most consolidated doctrinal opinion is that the final civil decision is binding on the criminal court and according to the author of this paper this decision should be binding on the criminal court, as it cannot retry the same fact that has been resolved civilly. Moreover, the principle of legal certainty assists this opinion, as ultimately a legal certainty is required, which is essentially related to final court decisions. In this aspect, our domestic practice goes in this direction, i.e., that the final civil decision is binding on the court that reviews the criminal case, even though it is about two different judicial jurisdictions, namely civil jurisdiction and criminal judicial jurisdiction. However, under these circumstances as the time has come for this discussion to be resolved once and for all by the Supreme Court, which will have to come up with a calculating decision of case law, an orientation which will finally solve the dilemmas encountered in the doctrine but also in our case law.

\section{References}

Constitutional Court of the Republic of Albania. (2007). Decision no. 43, of 19.12.2007.

Constitutional Court of the Republic of Albania. (2008). Decision no. 24 of 12.11.20o8.

Constitutional Court of the Republic of Albania. (2012). Decision no. 6 of 17.02.2012.

Court of Appeals of Tirana of the Republic of Albania. (2019). Decision no. 255 of 20.02.2019. 
District Court of Tirana of the Republic of Albania. (2018). Decision no. 4718 of 16.11.2018.

ECtHR. "Kehaya and Others V. Bulgaria”, Applications nos. 47797/99 and 68698/o1, Judgement 12.04.2006.

ECtHR. "Georgiadis v. Greece", Application no. 21522/93, Judgement 29 May 1997.

ECtHR. "Hornsby v. Greece”, Application no. 18357/91, Judgement 19 March 1997.

Supreme Court of the Republic of Albania, Civil Section. (2010). Decision no. 84 of 23.02.2010. Barjamaj, I., \& Dumi, A. (2014). Creating and Organizing a New Field Decision-Making in the Albanian Legal Framework and European Integration. Academic Journal Of Interdisciplinary Studies, 3(3), 523. Retrieved from https://www.mcser.org/journal/index.php/ajis/article/view/3455/3396.

Islami, H., Hoxha, A., \& Panda, I. (2012). Criminal Procedure. Tirana: Morava.

Lara, D. (2019). Commentary of Criminal Procedure. Tirana: Morava.

Memini, V. (2013). The Execution of Final Judicial Decision as Part of Human Rights Legislation. Academic Journal Of Interdisciplinary Studies, 2(8), 333. Retrieved from https://www.mcser.org/journal/index.php/ajis/article/view/742. Code of Civil Procedure of the Republic of Albania.

Code of Criminal Procedure of the Republic of Albania

Constitution of the Republic of Albania. 